\title{
Protection of Specimens against Friction and Wear Using Titanium-Based Multicomponent Nanocomposite Coatings: A Review
}

\author{
A. D. Pogrebnjak ${ }^{a, *}$, A. V. Pshyk ${ }^{a}$, V. M. Beresnev ${ }^{b}$, and B. R. Zhollybekov ${ }^{a, c}$ \\ ${ }^{a}$ Sumy State University, ul. Rimskogo-Korsakova 2, Sumy, 40007 Ukraine \\ ${ }^{b}$ Kharkov National University, Maidan Svobody 4, Kharkov, 61022 Ukraine \\ ${ }^{c}$ Kara-Kalpak State University, ul. Akademika Ch. Abdirova 1, Nukus, 742000 Uzbekistan \\ *e-mail:alexp@i.ua \\ Received June 4, 2013
}

\begin{abstract}
A review of the experimental results of studying multicomponent nanocomposite protective coatings of various chemical compositions (TiAlCrYN, TiAlSiBN, TiAlSiCuN, CrTiAlSiN, and TiHfSiN/NbN/ $/ \mathrm{Al}_{2} \mathrm{O}_{3}$ ) developed in recent years is presented. An analysis of the available data on the chemical composition, hardness, oxidation resistance, thermal stability, friction, wear, adhesion strength, and corrosion properties of nanocomposite coatings with high physicomechanical characteristics is carried out. The application of the nanocomposite coatings in industry is exemplified using the performance characteristics of drills made from a high-speed steel covered with a multicomponent protective coating.
\end{abstract}

Keywords: multicomponent nanocomposite coatings, magnetron sputtering, mechanical and tribological characteristics, oxidation resistance

DOI: $10.3103 / \mathrm{S} 1068366614010073$

\section{INTRODUCTION}

One of the chief problems in materials science is to develop and study new materials with unique functional properties. Nanomaterials and nanotechnologies have become a priority trend in materials science in recent years $[1,2]$.

In order to gain a more penetrating fundamental insight into the processes of adhesion, friction, wear, indentation, and lubrication, the mechanism and dynamics of the interaction of two moving solids in contact, the dimensions of which vary from the atomic to micro scale should be investigated. The significance of studying single contacts between asperities in research into fundamental nano- and micromechanical, as well as micro- and nanotribological, properties of surfaces and interfaces has long been recognized [2-6].

Nanotribological and nanomechanical research are necessary for gaining a deeper fundamental insight into interfacial phenomena on small scales, as well as for investigating interfacial phenomena in micro- and nanostructures, which are used in magnetic-storage devices, nanotechnologies, and other important fields [2].

Nanocomposite coatings are a new generation of materials. The idea of nanocomposites is to combine the best properties of the components in a material in order to improve its physicomechanical, chemical, magnetic, and high-temperature properties, as well as to stabilize the nanostructure during the production and operation of a nanocomposite [7].

It is mentioned in a number of works that deal with methods for producing nanocomposite coatings [7-9] that magnetron sputtering is the best-suited method for their industrial production, since it possesses definite advantages over the other methods [9]. The main specific feature of magnetron sputtering is a strong effect of plasma whose density depends on the configuration of a magnetron system on the properties of the coatings.

\section{TRIBOLOGICAL CHARACTERISTICS OF TiAlCrYN NANOCOMPOSITE COATINGS}

Hard nanostructured coatings of transition-metal nitrides deposited using the PVD method can have a strong adhesion to a substrate, a high hardness, an increased oxidation resistance, and an excellent wear resistance $[10-15]$. It was shown in $[16,17]$ that the tribological characteristics of TiN and TiAlN coatings depended on their chemical composition: the coefficient of dry friction was $0.7-0.9$ and, after incorporating $\mathrm{V}, \mathrm{N}$ or $\mathrm{Cr}$ into these coatings, $0.2-0.25$, depending on the test environment [18]. Multicomponent and multilayer nanostructured coatings are currently 


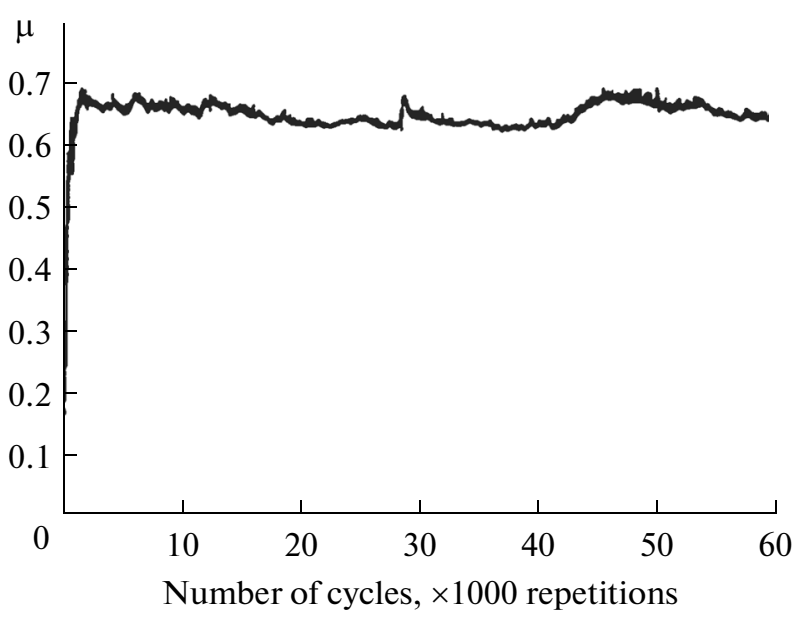

Fig. 1. Dependence of coefficient of friction of TiAlCrYN coating deposited on substrate made from P20 steel on number of repetitions (total sliding distance was $4.524 \mathrm{~m}$ ).

widely used to protect tools for various purposes $[19,20]$.

In [21], results of an experimental study of the friction and wear mechanisms for TiAlYN/TiAlCrN and TiAlY(O)N/Cr(O)N multicomponent and multilayer coatings deposited on a steel substrate using the magnetron method are presented. The roughness of the coatings deposited on the polished substrates was $R_{a}=$ $0.198 \mu \mathrm{m}$, while that of the coatings deposited on the prenitrided substrates was $R_{a}=0.378 \mu \mathrm{m}$. The hardness of the coatings was $26.6 \mathrm{GPa}$, irrespective of the grade of steel used to produce the substrate.
At the initial stage of the wear test of the TiAlCrYN coating, the coefficient of friction was $<0.2$; after a few thousands of cycles, it increased to 0.6-0.7. With an increase in the number of test cycles, splinter-like wear particles appeared at the edge of the wear track. In the steady sliding mode, the coefficient of friction was fairly stable and had high average values, which were mentioned above, while the friction curve (Fig. 1) shows irregular fluctuations of the coefficient of friction.

Table 1 presents the results of measurements the coefficient of friction and the wear factor for all the specimens tested in [21]: the coefficient of friction of the TiAlCrYN coating is substantially higher than that of the TiAlN/VN coating based on the nitride of the different transition metal $(\mu=0.4-0.5)$ [21].

It is pointed out in [21] that, with increasing thickness of the nitrided layer, the coefficient of friction decreases; at a depth of nitriding of $270 \mu \mathrm{m}$, an extremely high wear factor is observed. The wear factor remains by two or three orders of magnitude lower than that of the unnitrided steel. The authors of [21] also mention the effect of the relative humidity on the coefficient of friction of TiAlCrYN coatings.

High-resolution SEM examinations of TiAlCrYN coatings after the wear tests have shown the presence of splinter-like wear particles located along the direction of sliding, as well as the absence of cracks and delaminated areas (Fig. 2). The authors failed removing the splinter-like wear particles using acetone, which proves their strong adhesion to the nitride coating.

According to the results of the wear tests of the coatings (Table 2 in [21]), duplex processes of plasma nitriding, which precede the magnetron sputtering of

Table 1. Adhesion strength $\left(L_{\mathrm{c}}, \mathrm{N}\right)$, coefficient of friction $(\mu)$, and wear factor $\left(k_{c}, 10^{-16} \mathrm{~m}^{3} \mathrm{~N}^{-1} \mathrm{~m}^{-1}\right)$ of TiAlCrYN coating deposited on substrates made of various steels [21]

\begin{tabular}{|c|c|c|c|c|}
\hline \multirow{2}{*}{ Coating } & \multirow{2}{*}{ Substrate material } & \multirow{2}{*}{ Adhesion $L_{\mathrm{c}}$} & \multicolumn{2}{|c|}{ Friction and wear } \\
\hline & & & $\mu$ & $k_{c}$ \\
\hline Uncoated & M2 & - & 0.73 & 1200 \\
\hline TiAlCrYN & M2 & $46.0 \pm 3.0$ & 0.70 & 12.65 \\
\hline Uncoated & H13 & - & 0.71 & 3130 \\
\hline TiAlCrYN & $\mathrm{H} 13$ & $26.8 \pm 2.3$ & 0.65 & 51.5 \\
\hline TiAlCrYN & Nitrided H13 & $48.4 \pm 1.2$ & 0.67 & 5.16 \\
\hline TiAlCrYN & P20 & $20.7 \pm 3.5$ & 0.66 & 3.91 \\
\hline TiAlCrYN & Nitrided P20 & $73.0 \pm 3.6$ & 0.61 & 3.57 \\
\hline Uncoated & Nitrided S106(150 $\mu)$ & - & 0.74 & 2660 \\
\hline Uncoated & Nitrided S106(270 $\mu)$ & - & 0.75 & 438 \\
\hline Uncoated & Nitrided S106(400 $\mu)$ & - & 0.76 & 582 \\
\hline TiAlCrYN & Nitrided S106(150 $\mu)$ & $47.9 \pm 2.3$ & 0.67 & 15.9 \\
\hline TiAlCrYN & Nitrided S106(270 $\mu)$ & $46.2 \pm 2.6$ & 0.68 & 19.5 \\
\hline TiAlCrYN & Nitrided S106(400 $\mu)$ & $27.4 \pm 0.9$ & 0.68 & 11.3 \\
\hline
\end{tabular}


the TiAlCrYN coatings, efficiently improve the wear resistance of fairly soft surfaces.

In a $\mathrm{Cr}-\mathrm{Ti}-\mathrm{Al}-\mathrm{O}$ tribofilm, the basic chemical bonds were the bonds between the metal and oxygen atoms, despite a small amount of oxygen. Since the $\mathrm{Me}-\mathrm{O}$ bonds have a higher shear resistance than the $\mathrm{V}-\mathrm{O}$ bonds, the TiAlCrYN coatings, which contain $\mathrm{Cr}-\mathrm{O}, \mathrm{Al}-\mathrm{O}$, and $\mathrm{Ti}-\mathrm{O}$ bonds, possess higher coefficients of friction than the TiAlN/VN coatings [21].

\section{EFFECT OF CONCENTRATION OF Si ON TRIBOLOGICAL CHARACTERISTICS OF NANOCOMPOSITE TiAlSiCuN COATINGS [22]}

She, Muders, et al. studied the effect of the concentration of silicon on the tribological characteristics of nanocomposite TiAlSiCuN coatings [22]. The coatings of different stoichiometric compositions $\left(\mathrm{Ti}_{0.43} \mathrm{Al}_{0.48} \mathrm{Si}_{0.06} \mathrm{Cu}_{0.03} \mathrm{~N}\right.$ and $\mathrm{Ti}_{0.45} \mathrm{Al}_{0.42} \mathrm{Si}_{0.10} \mathrm{Cu}_{0.03} \mathrm{~N}$ ) consisted of the $\mathrm{Ti}-\mathrm{Al}-\mathrm{N}$ nanocrystalline phase and $\mathrm{Cu}$, while $\mathrm{Si}$ was present in the amorphous phase in the form of either silicon nitride or usual silicon (Fig. 1 in [22]). It has been found that the $\mathrm{Ti}_{0.54} \mathrm{Al}_{0.42} \mathrm{Si}_{0.01} \mathrm{Cu}_{0.03} \mathrm{~N}$ coating contained a solid solution and that the segregation of $\mathrm{Ti}-\mathrm{Al}-\mathrm{Si}-\mathrm{N}$ nanocrystals in the amorphous $\mathrm{Si}_{3} \mathrm{~N}_{4}$ matrix led to the formation of a nanocomposite nc-TiAlN $/ \mathrm{Si}_{3} \mathrm{~N}_{4}$ film in both $\mathrm{Ti}_{0.43} \mathrm{Al}_{0.48} \mathrm{Si}_{0.06} \mathrm{Cu}_{0.03} \mathrm{~N}$ and $\mathrm{Ti}_{0.45} \mathrm{Al}_{0.42} \mathrm{Si}_{0.10} \mathrm{Cu}_{0.03} \mathrm{~N}$ (Figs. 1 and 2 in [22]). The formation of the nanocomposite nc-TiAlN $/ \mathrm{Si}_{3} \mathrm{~N}_{4}$ film was a characteristic of the process of self-organization, which occurred during deposition and was extensively studied previously $[23,24]$.

The film $\mathrm{Ti}_{0.54} \mathrm{Al}_{0.42} \mathrm{Si}_{0.01} \mathrm{Cu}_{0.03} \mathrm{~N}$ with the lowest concentration of silicon had a surface roughness of $0.9 \mathrm{~nm}$, which then diminished as the concentration of $\mathrm{Si}$ decreased $(7.7$ and $6.5 \mathrm{~nm}$ for the $\mathrm{Ti}_{0.43} \mathrm{Al}_{0.48} \mathrm{Si}_{0.06} \mathrm{Cu}_{0.03} \mathrm{~N}$ and $\mathrm{Ti}_{0.45} \mathrm{Al}_{0.42} \mathrm{Si}_{0.10} \mathrm{Cu}_{0.03} \mathrm{~N}$ films, respectively).

In comparison with the $\mathrm{Ti}-\mathrm{Al}-\mathrm{Si}-\mathrm{N}$ films without $\mathrm{Cu}$ additives $[25,26]$, the $\mathrm{Ti}-\mathrm{Al}-\mathrm{Si}-\mathrm{Cu}-\mathrm{N}$ films

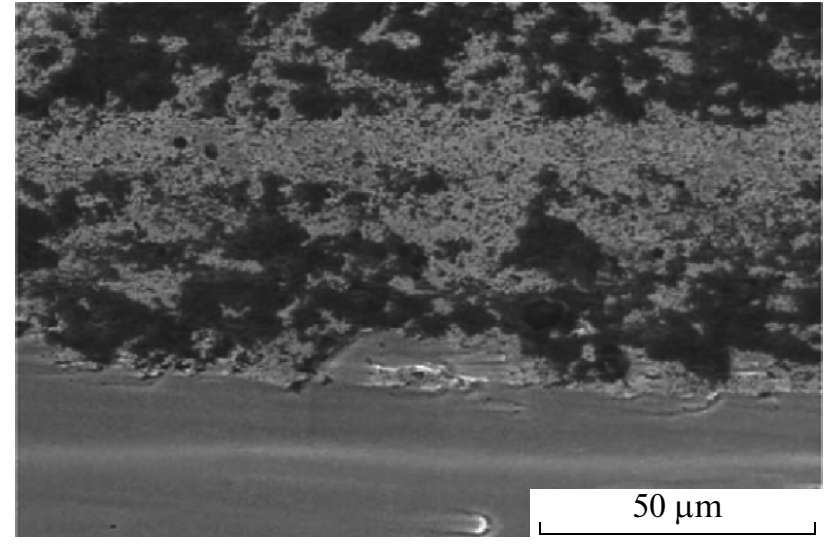

Fig. 2. High-resolution secondary-electron image of middle of wear track on surface of TiAlCrYN coating.

have definitely lower values of the coefficient of friction, which apparently can be due to the lubricating effect of the soft copper phase in the course of the sliding of a diamond indenter over a film and to a small crystalline grain size.

During the nanoscratch tests of the films, it was found that, with an increase in the concentration of $\mathrm{Si}$ in a film, the critical load first substantially grew (to $55 \mathrm{~N}$ ) for the $\mathrm{Ti}_{0.43} \mathrm{Al}_{0.48} \mathrm{Si}_{0.06} \mathrm{Cu}_{0.03} \mathrm{~N}$ film and, with a further increase in the concentration of $\mathrm{Si}$ in the $\mathrm{Ti}_{0.45} \mathrm{Al}_{0.42} \mathrm{Si}_{0.10} \mathrm{Cu}_{0.03} \mathrm{~N}$ film, did not considerably increase (Fig. 7 in [22]). The film with the lowest concentration of silicon was characterized by the lightest critical load $(36 \mathrm{~N})$. The adhesion of the films to the substrates undoubtedly increased with decreasing the crystallite size [22].

It was determined from the depth profiles of the wear tracks of the films (Fig. 3) that the $\mathrm{Ti}_{0.45} \mathrm{Al}_{0.42} \mathrm{Si}_{0.10} \mathrm{Cu}_{0.03} \mathrm{~N}$ film had the deepest wear track $(0.7 \mu \mathrm{m})$ in comparison with the other harder films. The $\mathrm{Ti}_{0.43} \mathrm{Al}_{0.48} \mathrm{Si}_{0.06} \mathrm{Cu}_{0.03} \mathrm{~N}$ coating with a hardness of $24.27 \mathrm{GPa}$ demonstrated the shallower wear track $(0.3 \mu \mathrm{m})$.

Table 2. Tribological characteristics of multilayer $\mathrm{Ti}-\mathrm{Hf}-\mathrm{Si}-\mathrm{N} / \mathrm{NbN} / \mathrm{Al}_{2} \mathrm{O}_{3}$ coating [37]

\begin{tabular}{l|c|c|c|c}
\hline \multirow{2}{*}{ Specimen } & \multicolumn{2}{|c|}{ Coefficient of friction $\mu$} & \multicolumn{2}{c}{ Wear factor, $\mathrm{mm}^{3} \mathrm{~N}^{-1} \mathrm{~m}^{-1}$} \\
\cline { 2 - 5 } & initial & during tests & counterbody $\left(\times 10^{-5}\right)$ & specimen $\left(\times 10^{-5}\right)$ \\
\hline Steel 3 & 0.204 & 0.674 & 0.269 & 35.36 \\
\hline $\mathrm{Steel} / \mathrm{Al}_{2} \mathrm{O}_{3}(200 \mu \mathrm{m})$ & 0.038 & 0.959 & 1.61 & 22.39 \\
\hline $\begin{array}{l}\mathrm{Steel} / \mathrm{Al}_{2} \mathrm{O}_{3}(200 \mu \mathrm{m}) \\
\mathrm{NbN}+\mathrm{TiHfSiN}^{*}\end{array}$ & 0.256 & 0.265 & 0.184 & 2.571 \\
\hline $\begin{array}{l}\mathrm{Steel} / \mathrm{Al}_{2} \mathrm{O}_{3}(180 \mu \mathrm{m}) \\
\text { Section} / \mathrm{NbN}+\mathrm{TiHfSiN}(\mathrm{P}-3)\end{array}$ & 0.02 & 0.001 & 4.51 & 21.43 \\
\hline $\begin{array}{l}\text { Steel} / \mathrm{Al}_{2} \mathrm{O}_{3}(180 \mu \mathrm{m}) \\
\text { Section} / \mathrm{NbN}+\mathrm{TiHfSiN}(\mathrm{P}-8)\end{array}$ & 0.314 & 0.384 & 0.936 & 2.818 \\
\hline
\end{tabular}




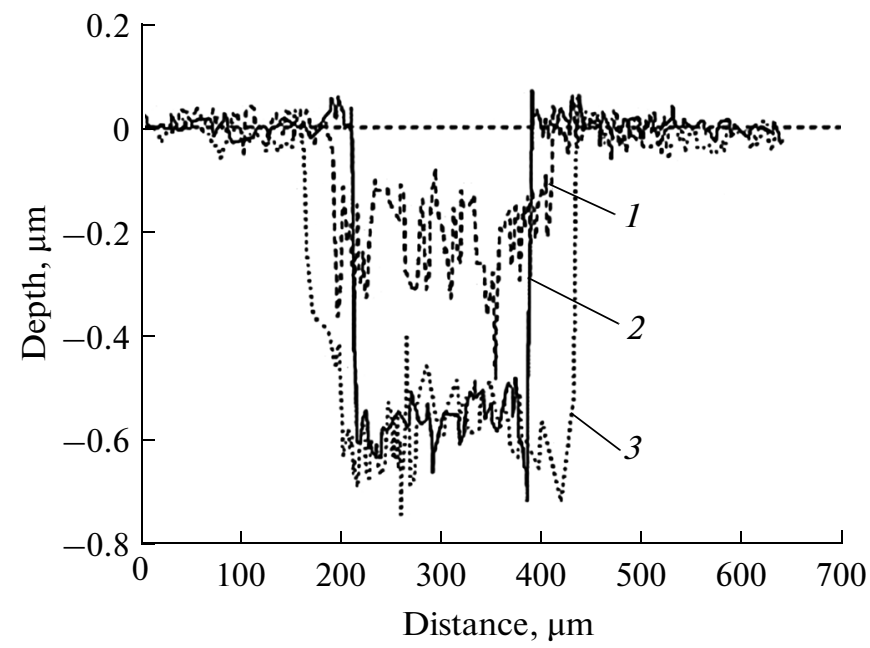

Fig. 3. Depth profiles of wear track on surfaces of $\mathrm{Ti}-\mathrm{Al}-$ $\mathrm{Si}-\mathrm{Cu}-\mathrm{N}$ films obtained under load of $5 \mathrm{~N}$ : (1) $\mathrm{Ti}_{0.43} \mathrm{Al}_{0.48} \mathrm{Si}_{0.06} \mathrm{Cu}_{0.03} \mathrm{~N}(H=24.47 \pm 4.09 \mathrm{GPa})$;

(2) $\mathrm{Ti}_{0.54} \mathrm{Al}_{0.42} \mathrm{Si}_{0.01} \mathrm{Cu}_{0.03} \mathrm{~N}(H=19.49 \pm 2.77 \mathrm{GPa})$; and

(3) $\mathrm{Ti}_{0.45} \mathrm{Al}_{0.42} \mathrm{Si}_{0.10} \mathrm{Cu}_{0.03} \mathrm{~N}(H=15.84 \pm 1.67 \mathrm{GPa})$.

It can be seen in the dependences of the wear rate of the films as a function of the concentration of $\mathrm{Si}$ (Fig. 4) that the wear rate of the hardest $\mathrm{Ti}_{0.43} \mathrm{Al}_{0.48} \mathrm{Si}_{0.06} \mathrm{Cu}_{0.03} \mathrm{~N}$ film was $1.3 \times 10^{-5} \mathrm{~mm}^{3} /(\mathrm{N} \mathrm{m})$ and that the softest $\mathrm{Ti}_{0.45} \mathrm{Al}_{0.42} \mathrm{Si}_{0.10} \mathrm{Cu}_{0.03} \mathrm{Na}$ film had the highest wear rate $\left(3.9 \times 10^{-5} \mathrm{~mm}^{3} /(\mathrm{N} \mathrm{m})\right)$.

\section{OXIDATION RESISTANCE OF TiAICrYN, CrTiAlSiN, AND TiAlSiBN COATINGS}

In last years, considerable efforts have been concentrated on the development of hard thermally stable nanocomposite coatings with a high oxidation resistance at temperatures of above $1000^{\circ} \mathrm{C}$. These coatings have found various applications, including high-speed cutting, as well as the protection of some mechanical spare parts (turbine blades, etc.), rockets, and spacecrafts for orbital flights [27].

It was assumed in [28] that the oxidation resistance of nanocomposites depended primarily on their elemental and phase compositions. Based on these assumptions, the oxidation resistance was progressively increased: $\mathrm{TiC}\left(\sim 400^{\circ} \mathrm{C}\right)$, $\mathrm{TiN}\left(\sim 650^{\circ} \mathrm{C}\right)$, ( Ti,Al)N $\left(\sim 850^{\circ} \mathrm{C}\right),(\mathrm{Ti}, \mathrm{Al}, \mathrm{Cr}, \mathrm{Y}) \mathrm{N}\left(\sim 930^{\circ} \mathrm{C}\right)$, as well as $\mathrm{Me}-\mathrm{Si}-\mathrm{N}$ nanocomposites with a low $(\leq 10 \%)$ concentration of Si $\left(\sim 910^{\circ} \mathrm{C}\right)$ and $\mathrm{MeN} / \mathrm{MeN}$ mutlilayers, e.g., TiAlN $/ \mathrm{CrN}\left(\sim 950^{\circ} \mathrm{C}\right)$; here $\mathrm{Me}=\mathrm{Ti}, \mathrm{Zr}, \mathrm{Cr}$, $\mathrm{W}, \mathrm{Ta}, \mathrm{Mo}, \mathrm{Nb}$, etc. It can be seen from this sequence that the mixture of a film with a suitable element improves its oxidation resistance at high temperatures, but only at temperatures not exceeding $1000^{\circ} \mathrm{C}$. Moreover, at high temperatures, the oxidation resistance of hard coatings depends on their structure.

There is the only efficient method for improving the oxidation resistance of hard coatings, which is based on suppression the crystallization of a material, i.e., on the elimination of grains and the subsequent elimination of a continuous bond between the surface of the coating and the substrate at the grains through the surrounding boundaries; in other words, this method is based on the formation of an amorphous structure. When an amorphous coating is used, the substrate does not contact with the environment and, therefore, does not undergo oxidation. The oxidation resistance of coatings is mainly determined by the thermal stability of their amorphous structure and the diffusion of elements from the substrate to the coating and backwards, which can stimulate the crystallization of the coatings [28].

In [27], the investigated coatings were annealed for $2 \mathrm{~h}$ at temperatures of $600-1000^{\circ} \mathrm{C}$. An analysis of the Raman spectra (Figs. 5-7 in [27]) has shown that

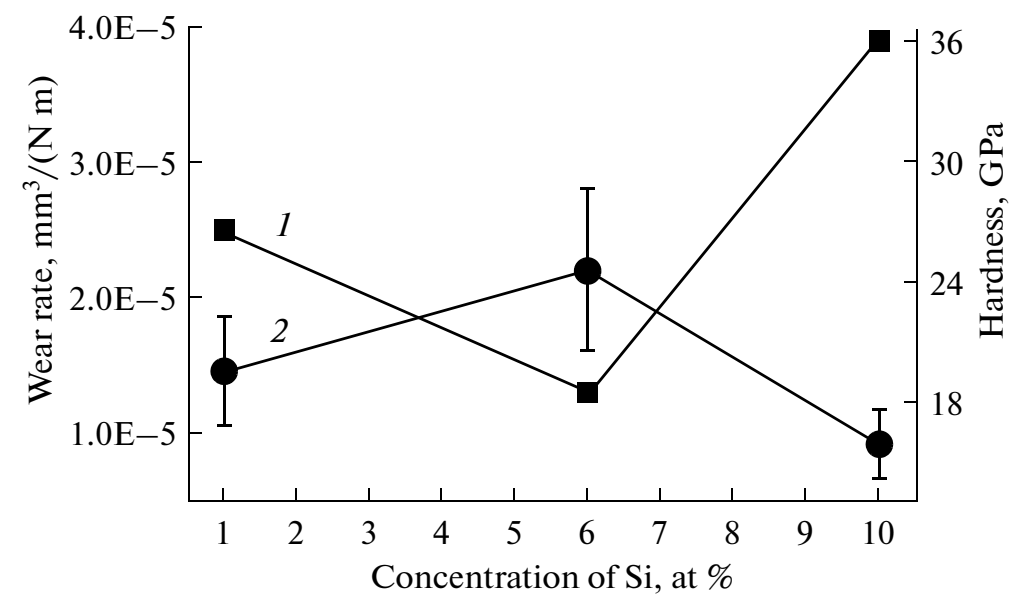

Fig. 4. Wear rate and hardness of $\mathrm{Ti}-\mathrm{Al}-\mathrm{Si}-\mathrm{Cu}-\mathrm{N}$ films as functions of concentration of $\mathrm{Si}$ : (1) wear rate and (2) hardness. 


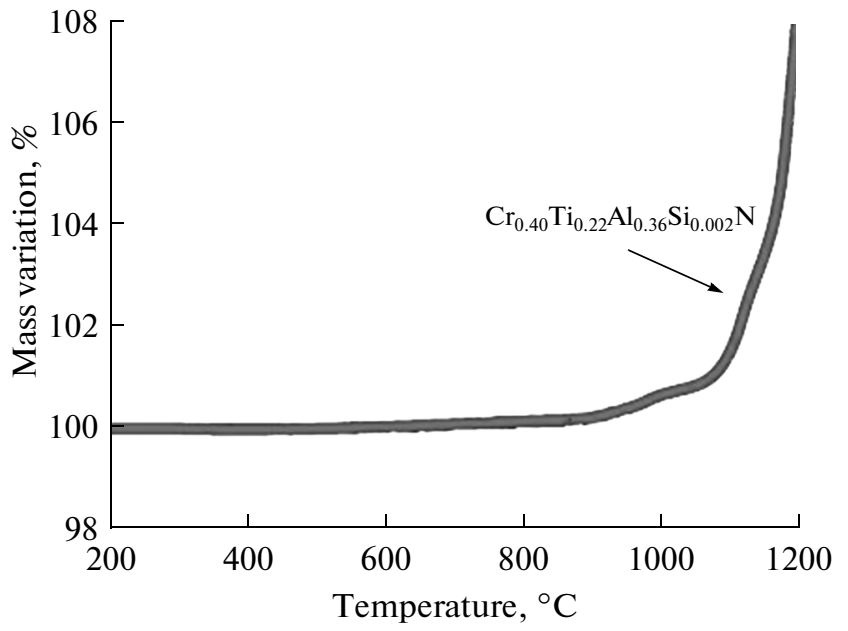

Fig. 5. Results of thermogravimetric analysis of $\mathrm{Cr}_{0.40} \mathrm{Ti}_{0.22} \mathrm{Al}_{0.36} \mathrm{Si}_{0.02} \mathrm{~N}$ coating in air flow at rate of heating of $20^{\circ} \mathrm{C} / \mathrm{min}$.

nitrogen atoms are removed from the TiAlCrYN films. It has also been found that, for the specimens of the first series, the process of oxidation begins at a temperature of $700^{\circ} \mathrm{C}$, while the noticeable transformation of the lines in the Raman spectrum only begins at a temperature of $600^{\circ} \mathrm{C}$. The two peaks in the spectrum that appear at a temperature of $650^{\circ} \mathrm{C}$ correspond to $\mathrm{Cr}_{2} \mathrm{O}_{3}$ and $(\mathrm{Al}, \mathrm{Ti})_{2} \mathrm{O}_{3}$. The authors attribute the low oxidation resistance of the specimens of this series to the low concentration of $\mathrm{Al}$, which is present in the coating. The spectrum also contains the $\mathrm{Y}_{2} \mathrm{O}_{3}$ lines whose low intensity can apparently be due to a small amount of amorphous $\mathrm{Y}_{2} \mathrm{O}_{3}$, which was formed in the coating after annealing, or to the fact that the efficiency of the scatter of $\mathrm{Cr}_{2} \mathrm{O}_{3}$ and $\mathrm{TiO}_{2}$ is much higher than that of $\mathrm{Y}_{2} \mathrm{O}_{3}$.

However, the authors of that work observed no substantial transformations of the spectra of the specimens from the second series up to an annealing temperature of $800^{\circ} \mathrm{C}$. At a temperature of $900^{\circ} \mathrm{C}$, the peaks of the $\mathrm{TiO}_{2}$ phase appeared, the intensity of which increased significantly after annealing at a temperature of $1000^{\circ} \mathrm{C}$. The results of these studies have shown that the oxidation resistance of the coatings of this series is up to $900^{\circ} \mathrm{C}$ [27].

Improving the oxidation resistance of Y-based hard nanocomposite coatings was based on several mechanisms $[29,30]$. It was assumed that $Y$ accumulates at grain boundaries, which serve as a fast way to diffuse oxygen molecules. In addition, agglomerates of $\mathrm{Y}$ hamper the coarsening of grains of the nanocrystalline coating due to annealing and, therefore, improve the oxidation resistance of the TiAlCrYN coatings.

In [31], CrTiAlSiN coatings were produced by the cathode sputtering of a target. The coatings were $700 \pm 50 \mathrm{~nm}$ thick.

An analysis of the chemical composition of these coatings showed that their atomic stoichiometry was $\mathrm{Cr}_{0.40} \mathrm{Ti}_{0.22} \mathrm{Al}_{0.36} \mathrm{Si}_{0.02} \mathrm{~N}$. X-ray diffraction showed the presence of a solid solution in these coatings.

Using thermogravimetric analysis, it was found that, starting from a temperature of $\sim 870^{\circ} \mathrm{C}$, an increase in the mass of the $\mathrm{Cr}_{0.40} \mathrm{Ti}_{0.22} \mathrm{Al}_{0.36} \mathrm{Si}_{0.02} \mathrm{~N}$ coating occurred (Fig. 5); at temperatures above $1080^{\circ} \mathrm{C}$, the greatest increase in the mass was observed.

In order to estimate the characteristic of oxidation, these coating was annealed for $2 \mathrm{~h}$ at $900^{\circ} \mathrm{C}$. Electronmicroscopic images of the oxidized coating (Fig. 6)
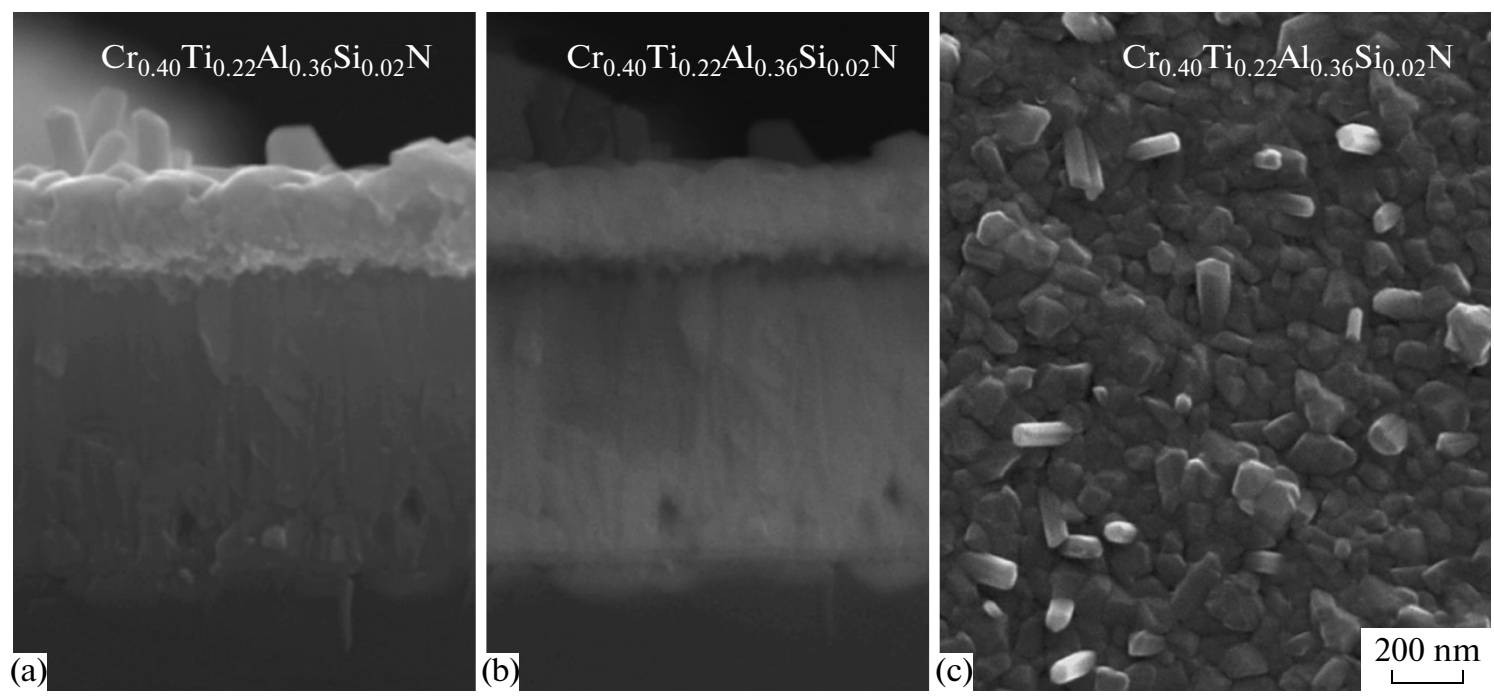

Fig. 6. (a) Image of cross section (FESEM) of $\mathrm{Cr}_{0.40} \mathrm{Ti}_{0.22} \mathrm{Al}_{0.36} \mathrm{Si}_{0.02} \mathrm{~N}$ coating oxidized for $2 \mathrm{~h}$ at temperature of $900^{\circ} \mathrm{C}$, (b) secondary-electron image, and (c) image of surface of coating. 


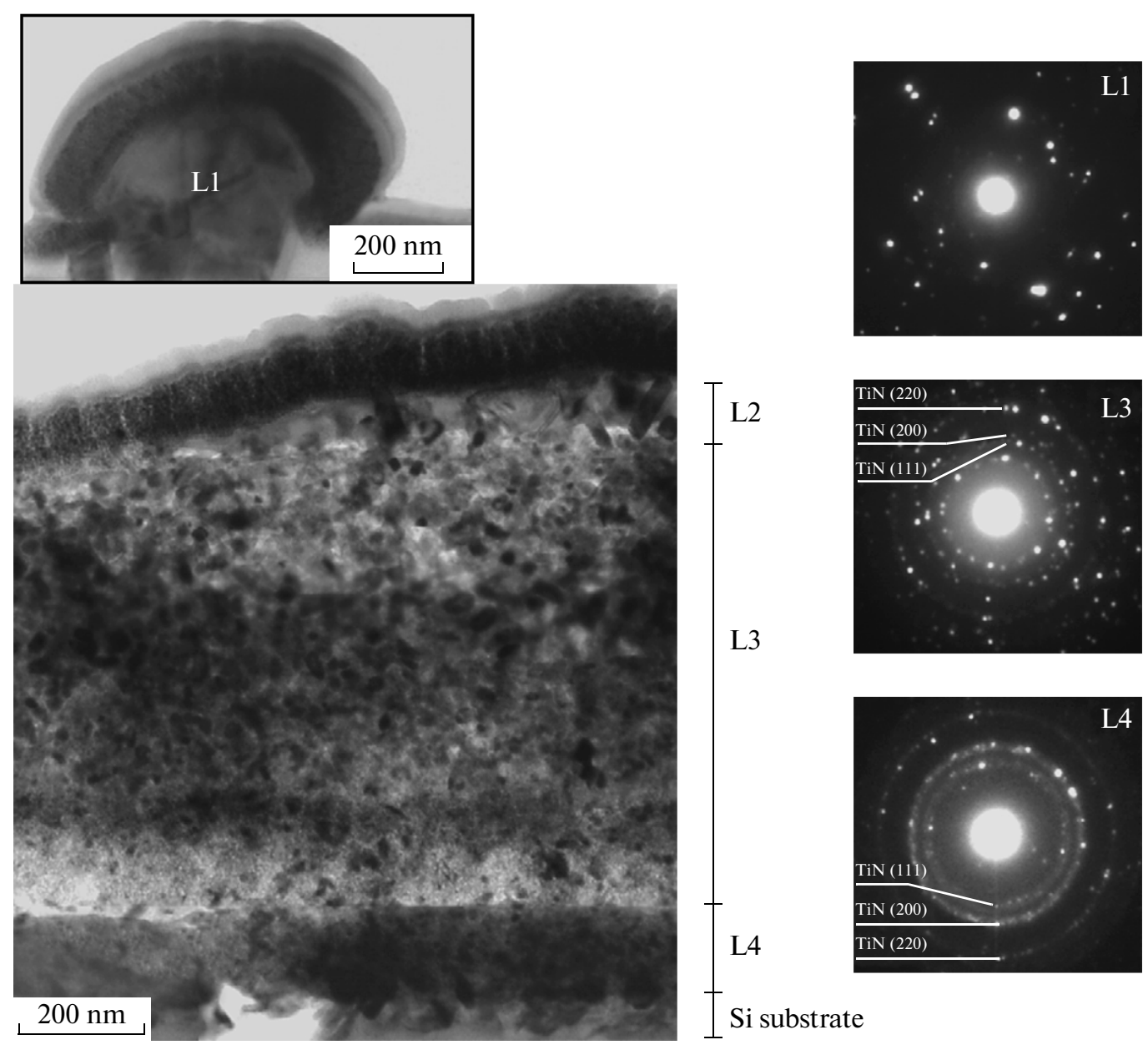

Fig. 7. Dark-field image of cross section (TEM) of annealed TiAlSiBN coating with layers indicated and diffraction patterns of layers.

showed the presence of a $0.2-\mu \mathrm{m}$-thick oxide layer on the surface of the $\mathrm{Cr}_{0.40} \mathrm{Ti}_{0.22} \mathrm{Al}_{0.36} \mathrm{Si}_{0.02} \mathrm{~N}$ coating. It is important to note that the coating with a higher concentration of $\mathrm{Al}$ was less oxidized. The oxide layer on the surface of the $\mathrm{Cr}_{0.36} \mathrm{Al}_{0.57} \mathrm{Si}_{0.07} \mathrm{~N}$ coating was thinner than on the surface of the $\mathrm{Cr}_{0.40} \mathrm{Ti}_{0.22} \mathrm{Al}_{0.36} \mathrm{Si}_{0.02} \mathrm{~N}$ coating.

Results of X-ray diffraction showed the presence of the $\mathrm{Cr}_{2} \mathrm{O}_{3}, \mathrm{TiO}_{2}$, and $\mathrm{Al}_{2} \mathrm{O}_{3}$ phases in the oxidized $\mathrm{Cr}_{0.40} \mathrm{Ti}_{0.22} \mathrm{Al}_{0.36} \mathrm{Si}_{0.02} \mathrm{~N}$ coating, in addition to the nitride phases, due to the replacement of nitrogen by oxygen after annealing at $900^{\circ} \mathrm{C} \mathrm{[31].}$

Results of X-ray photoelectron spectroscopy (XPS) obtained at various depths under the surface of the oxidized $\mathrm{Cr}_{0.40} \mathrm{Ti}_{0.22} \mathrm{Al}_{0.36} \mathrm{Si}_{0.02} \mathrm{~N}$ coating showed that, on the entire area of the oxide layer, titanium, chromium, and aluminum oxides were formed (Figs. 4 and 5 in [31]); in the surface layer of the coating, the $\mathrm{TiO}_{2}$ phase was dominant, and the intensity of the peaks of this phase decreased with increasing depth under the surface of the coating.
Since the free Gibbs energy of the formation of oxide $\mathrm{Al}_{2} \mathrm{O}_{3}$ is the highest compared with those of oxides $\mathrm{Cr}_{2} \mathrm{O}_{3}, \mathrm{TiO}_{2}$, and $\mathrm{SiO}_{2}, \mathrm{Al}$ atoms subsequently form an $\mathrm{Al}_{2} \mathrm{O}_{3}$ protective layer, which hampers the interdiffusion of the components of the film. However, at $900-1000^{\circ} \mathrm{C}$, the parabolic constant of the oxidation rate of $\mathrm{TiO}_{2}$ is higher than that of $\mathrm{Al}_{2} \mathrm{O}_{3}$ and $\mathrm{Cr}_{2} \mathrm{O}_{3}$. After oxidation at $900^{\circ} \mathrm{C}$, on the alumina and chromium oxide layer, oxide $\mathrm{TiO}_{2}$ grows at an increased rate. During heating, cracks appear on the surface of the coating due to the different coefficients of thermal expansion of the film and oxides $\left(10.5 \times 10^{-6} / \mathrm{K}\right.$ for $\mathrm{TiO}_{2}, 8.4 \times 10^{-6} / \mathrm{K}$ for $\mathrm{Al}_{2} \mathrm{O}_{3}$, and $7 \times 10^{-6} / \mathrm{K}$ for $\mathrm{Cr}_{2} \mathrm{O}_{3}$ ) [31]. Therefore, Ti diffuses through the cracks in the composite $\mathrm{Al}_{2} \mathrm{O}_{3}-\mathrm{Cr}_{2} \mathrm{O}_{3}$ layer, then reacts with oxygen, and forms $\mathrm{TiO}_{2}$ on the surface of the coating. In the $\mathrm{Cr}_{0.40} \mathrm{Ti}_{0.22} \mathrm{Al}_{0.36} \mathrm{Si}_{0.02} \mathrm{~N}$ coating, predominant oxidation along columnar boundaries and the cracks in the composite $\mathrm{Al}_{2} \mathrm{O}_{3}-\mathrm{Cr}_{2} \mathrm{O}_{3}$ layer hampers the formation of a perfectly thin oxide layer. This is due to an increase in stresses in the course of high-temperature 
(a)

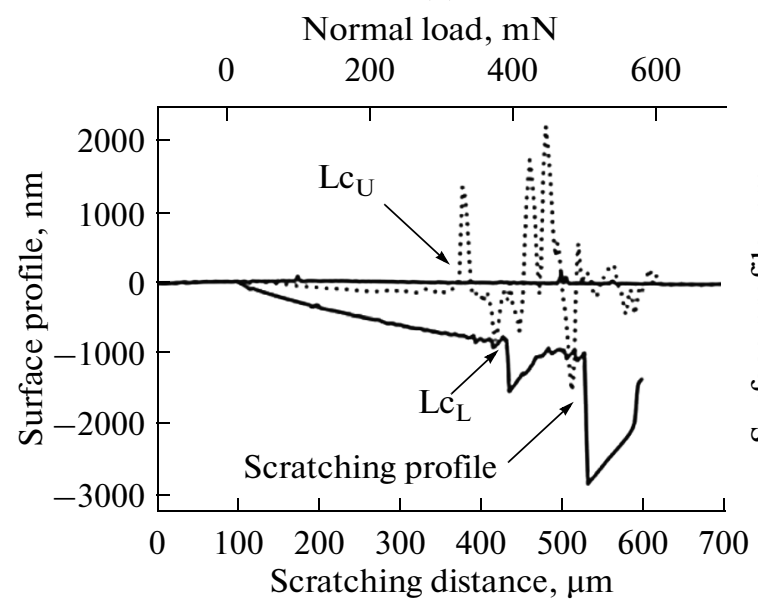

(c)

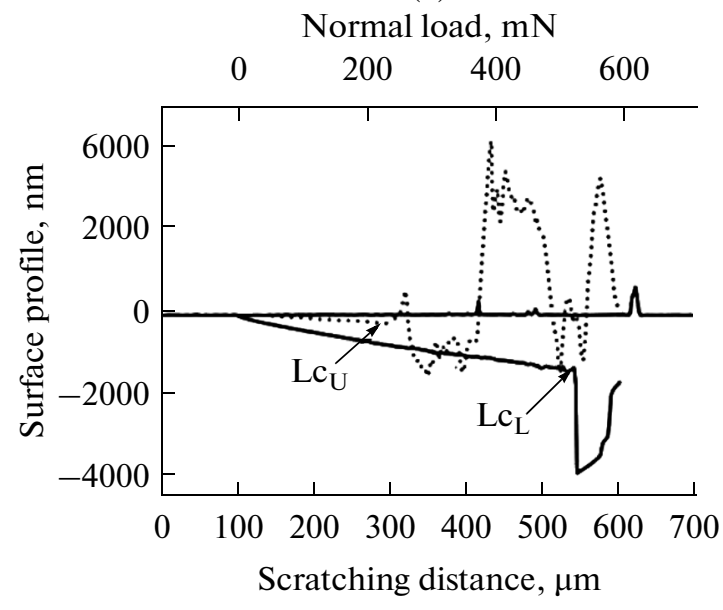

(b)

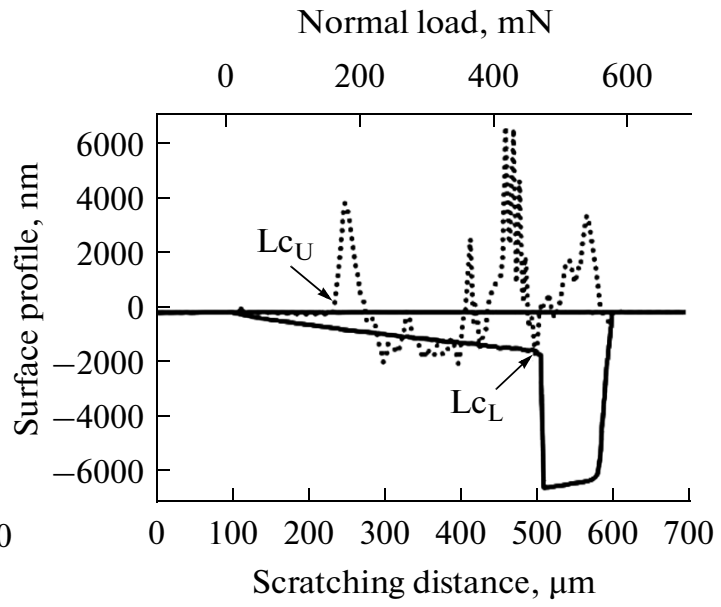

Fig. 8. Typical profiles of nanoscratch test and friction of specimens from series (a-c) 1-3 [46].

oxidation, as well as by thermal stresses induced by the different coefficients of thermal expansion of oxides, the unoxidized coating, and the substrate.

C. Paternoster et al. presented results of studying the effect of the annealing of nanocomposite TiAlSiBN coatings, which were produced by magnetron sputtering, at a temperature of $900^{\circ} \mathrm{C}$ [32]. The deposited coating consisted of a great amount of an amorphous phase and had a columnar structure. It was shown that oxidation led to a growth in the average grain size and the formation of a multilayer structure with various phase compositions (Fig. 7); i.e., surface layer L1 consisted of the $\mathrm{Al}_{2} \mathrm{O}_{3}$ phase (because of the diffusion of $\mathrm{Al}$ onto the free surface $[33,34])$, layer L2 contained the $\mathrm{TiO}_{2}+\mathrm{Al}_{2} \mathrm{O}_{3}$ phase, layer $\mathrm{L} 3$ consisted of the $\mathrm{TiN}$ phase, and layer L4 contained the TiN phase. The authors noted a decrease in the hardness of the coating after annealing [32]; all the layers of the coating had different hardnesses, which the authors' believed to be due to their different microstructures.

\section{ADHESION STRENGTH}

Nanoscratch tests of the TiAlCrYN coating sowed that, after achieving a load of $374 \mathrm{mN}$, the depth of indentation rose sharply and the coefficient of friction changed dramatically [27] (Fig. 8). This load was called critical and denoted as $L_{c}$. At this point, the coating was partly delaminated and fractured due to a high compressive stress produced by the indenter. The profile trace recorded after scanning showed that the coating fractured under loads below the critical load. The load that corresponded to the point at which the coating fractured after loading was denoted as $L_{c U}$. Bull et al. believe that this fracture results from the asynchronous recovery of the deformation at the coating-substrate interface [35, 36]; this deformation induced shear stresses directed along the interlayer, which led to the exfoliation of the coating. Based on the values of the critical loads, it can be clearly seen that the specimens from the third series had an increased adhesion strength compared to the specimens from the first and the second series (Fig. 8). 

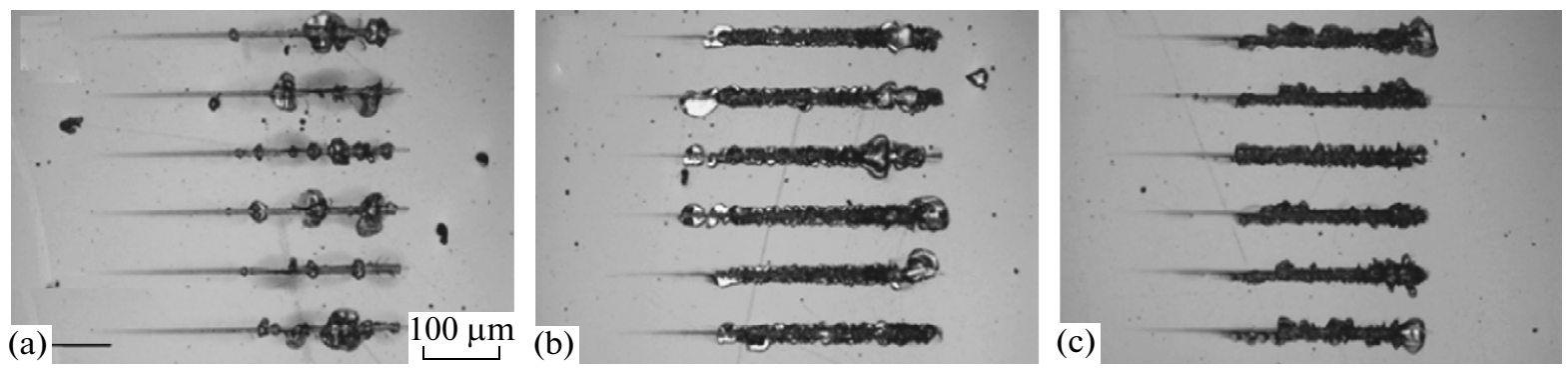

Fig. 9. Optical microphotos of scratch tracks obtained under load of $600 \mathrm{mN}$ for specimens from (a) first, (b) second, and (c) third series.

The optical images of the tracks obtained after the scratch test clearly show exfoliation after compression under the heavy loads, which were induced by high compressive stresses produced by the indenter, as well as recovery elastic exfoliation under the fairly light loads (Fig. 9). This was explained by wedge-type exfoliation, which consisted of semicircular cracks that propagated from the middle line of the scratch track. After achieving the critical load, all of the coatings were partly exfoliated. The optical images confirmed an increased adhesion resistance of the coatings from the third series as compared to those from the first and the second series (Fig. 9) [27].

\section{FRICTION AND WEAR}

Wear tests were carried out using a CETR UMT-2 microtribometer at the room temperature under a load of $2 \mathrm{~N}$ [27]; the counterbody was made from a stainless steel. Figure 10 shows the dependences of the coefficient of friction for three TiAlCrYN coatings deposited on the silicon substrates. The average coefficients of friction were 0.68 and 0.78 for specimens from the

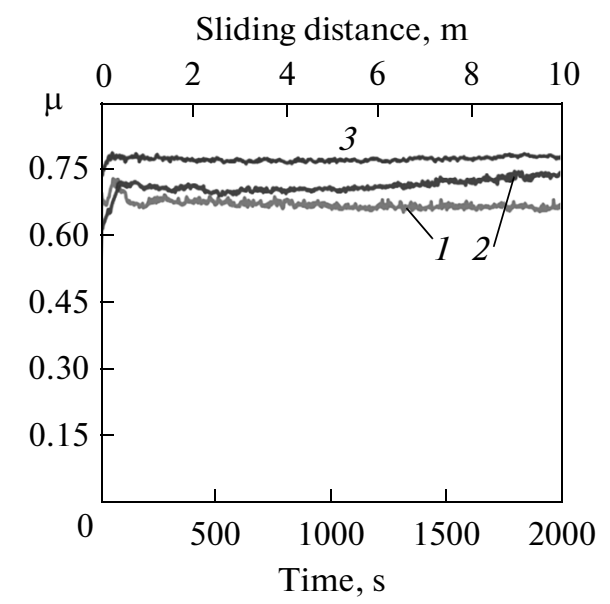

Fig. 10. Time dependences of coefficient of friction for three TiAlCrYN coatings: (1) specimen 1; (2) specimen 2; and (3) specimen 3 . The counterbody was a ball made from stainless steel. first and the second series, respectively, as well as $0.70-0.73$ for the specimen from the third series.

The optical photos presented in Fig. 11 show the signs of the microwear and oxidation of the coating worn out. Neither cracks no fracturing exfoliations were observed, which was indicative of a good fracture resistance of these coatings.

A. D. Pogrebnyak et al. reported results of studying a multilayer $\mathrm{Ti}-\mathrm{Hf}-\mathrm{Si}-\mathrm{N} / \mathrm{NbN} / \mathrm{Al}_{2} \mathrm{O}_{3}$ coating produced by HF-assisted cathode vacuum-arc deposition [37]. The results of the tribotests (Table 2) showed that the multicomponent (multilayer) coating deposited under a pressure of $P=0.3 \mathrm{~Pa}$ had the best characteristics (at the initial stage of the test, the coefficient of friction was 0.02 and then decreased to 0.001 ). In that paper, emphasis was placed on the effect of the parameters of deposition on the distribution of the concentration of the elements in the coating, which, in turn, governed its mechanical and tribological characteristics.

\section{CORROSION RESISTANCE}

Based on the Tafel dependences (Fig. 12), in was found that, unlike the uncoated specimens, the corrosion potential of the specimens covered with the TiAlCrYN coating shifted toward the positive values, which was indicative of a better corrosion resistance of the specimens covered with the TiAlCrYN coating than that of the uncoated specimens [27]. The rate of corrosion is proportional to the density of the corrosion current; therefore, a decrease in $i_{\text {corr }}$ for the coated specimens is indicative of their improved corrosion characteristics. The polarization resistance of the coatings covered with the TiAlCrYN coating also increased.

\section{PERFORMANCE CHARACTERISTICS OF DRILLS COVERED WITH TiAlCrYN COATING}

In [27], results of estimating the performance characteristics of TiAlCrYN coatings deposited on drills made from a high-speed steel, as well as on substrates made from a mild steel and silicon, by magnetron sputtering are presented. These specimens were covered with a TiAlCrYN coating at various densities of 

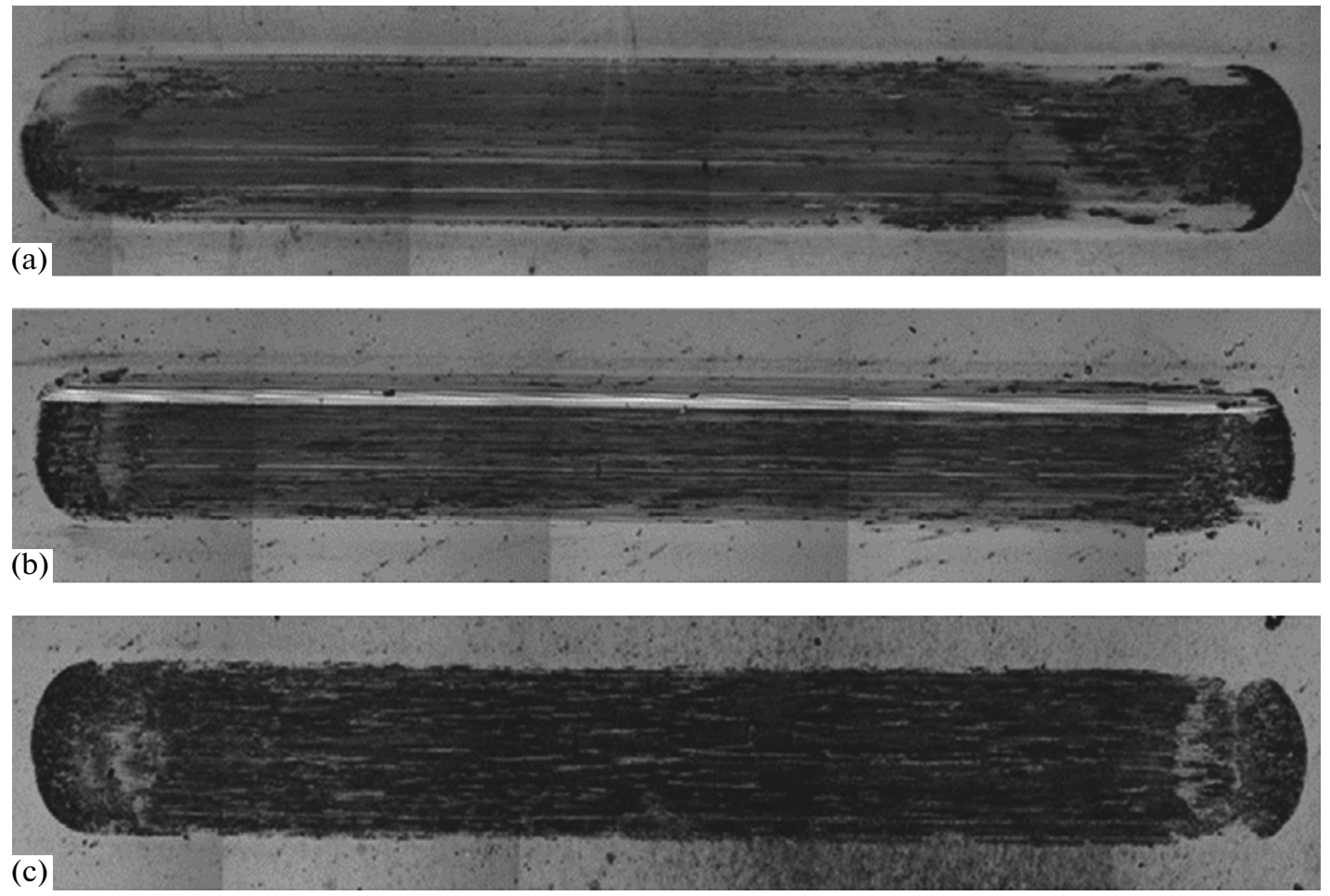

Fig. 11. Optical images of wear tracks on surfaces of TiAlCrYN coatings.

the power applied to the cathodes. As a result, three groups of the coatings were produced. The coatings were $1.5-2.5 \mu \mathrm{m}$ thick.

The coatings deposited at the various densities of the power had different chemical compositions; the results of X-ray photoelectron spectroscopy showed the presence of the $(\mathrm{Ti}, \mathrm{O}) \mathrm{N}, \mathrm{AlN}, \mathrm{CrN}, \mathrm{YN}$, and TiN phases in the coatings (Table 1 in [27]). The results of scanning electron microscopy were indicative of the presence of a columnar structure in the coatings; the Ti interlayer was $300 \mathrm{~nm}$ thick.

The authors of [27] explained the high values of the hardness and the modulus of elasticity (28 and $338 \mathrm{GPa}, 30$ and $318 \mathrm{GPa}$, and 25 and $295 \mathrm{GPa}$ for specimens 1,2 , and 3 , respectively) by a short interatomic spacing, the covalent nature of the bonds, and a small grain size of the TiAlCrYN coatings.

It is known $[38,39]$ that coatings deposited on surfaces of drills and other tools, which experience friction and high temperatures, extends their service life and improves their quality. In order to estimate the performance characteristics of drills made from a high-speed steel, which were covered with the nanocomposite TiAlCrYN coatings, dry drill tests were carried out using a $12-\mathrm{mm}$-thick plate made from a stainless steel. The test conditions are presented in Table 3 .

Based on the test results and the images of the drill blade, as well as its edge and curvature radius, obtained before and after the tests (Fig. 13), it was found that, after drilling 132 holes, the specimens from the first series became blunt. However, the drills from the second series became blunt after drilling 525 holes. The largest number of holes (650) was produced using the specimens from the third series; the specimens without the TiAlCrYN coating became blunt after drilling 50 holes. The values of the wear of the drill blade, as well as its edge and curvature radius, are presented in Table 3.

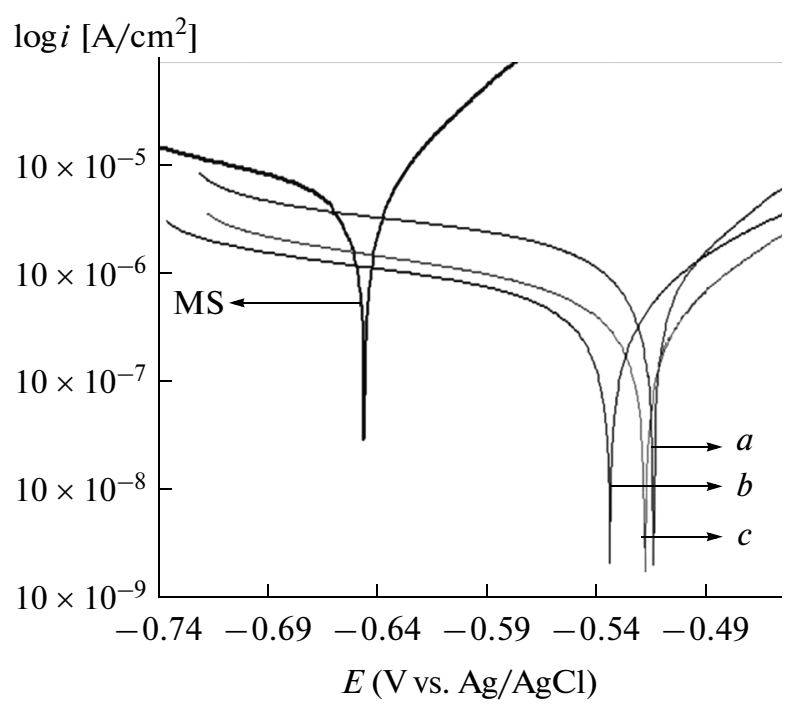

Fig. 12. Potentiodynamic polarization curves for mild steel (MS) and TiAlCrYN coatings deposited on MS: $(a)$ specimen $1 ;(b)$ specimen 2; and (c) specimen 3. 
Table 3. Conditions for estimating performance characteristics of drills made from high-speed steel and covered with TiAlCrYN coating

\begin{tabular}{l|c}
\hline \multicolumn{1}{c|}{ Test standard } & \\
\hline Test material & SS 304 \\
Speed of drilling & $800 \mathrm{rpm}$ \\
Rate of feed & $0.08 \mathrm{~mm} / \mathrm{rev}$ \\
Diameter of drill & $8 \mathrm{~mm}$ \\
Depth of drilling & $12 \mathrm{~mm}$ \\
Duration of drilling each hole & $11 \mathrm{~s}$ \\
Rate of penetration & $65 \mathrm{~mm} / \mathrm{min}$ \\
\hline
\end{tabular}

In the above-mentioned study, it has been finally shown that, in order to improve the oxidation and performance characteristics of the nanocomposite TiAlCrYN coatings, a reasonable control of the concentrations of $\mathrm{Ti}, \mathrm{Al}, \mathrm{Cr}$, and $\mathrm{Y}$ is required.

The authors of [27] showed that the characteristic, such as the geometry of a drill, the type of its treat- ment, the composition, thickness, and structure of a coating deposited on it, together with a method for depositing the coating, have a strong effect on the performance characteristics. In that work, it was clearly shown that the deposition of the nanocomposite TiAlCrYN coating on the drills extended their service life by more than twelve times.

Kok et al. compared the service life of drills made from a high-speed steel covered with a $\mathrm{Cr} / \mathrm{C}$ coating with that of drills covered with a TiAlCrYN coating [40]. The authors drew the conclusion that the service life of the drills covered with the nanocomposite TiAlCrYN coating was extended by more than eight times.

Luo et al. obtained similar results for mills covered with TiAlCrYN and TiAlN/VN coatings [41]. The service life of the mills covered with the TiAlN/VN coating was extended by more than three times, while the drills covered with the TiAlCrYN coating demonstrated good protection of the cutting blade without cracks, as well as delaminations and spalls.
Lip
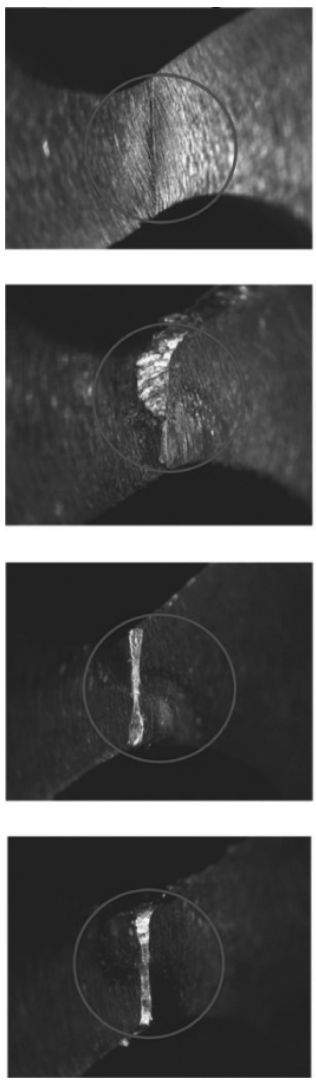

Curvature radius of tip
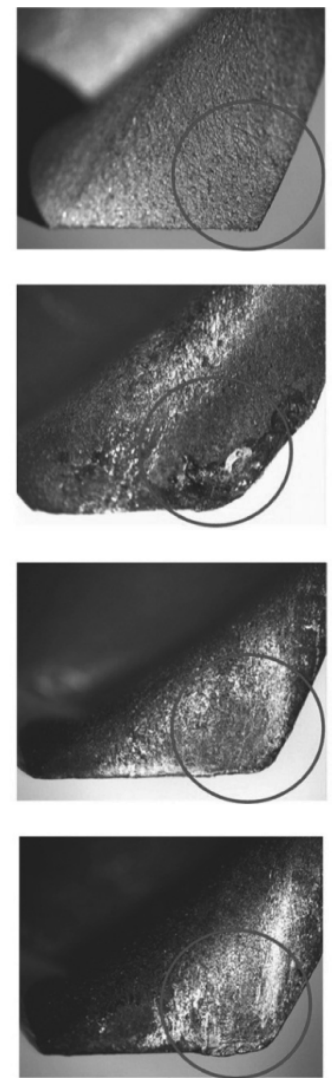

Cutting edge
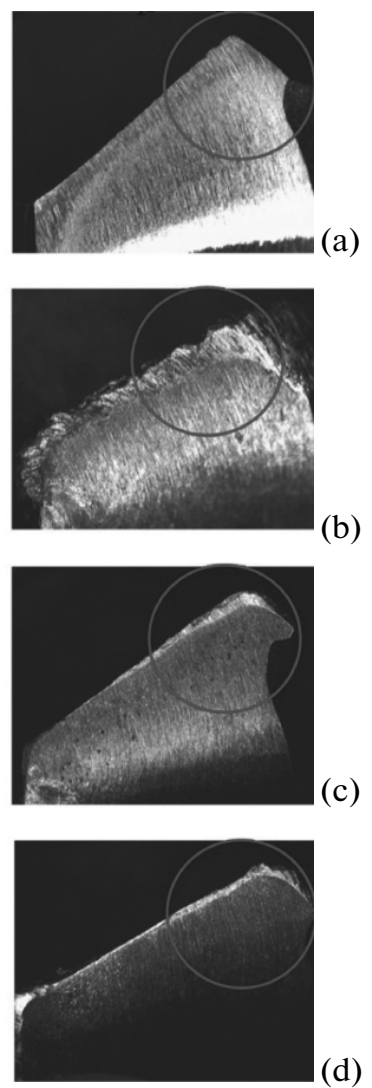

Fig. 13. Photos of drills made from stainless steel covered with nanocomposite TiAlCrYN coatings: (a) before drilling; (b) specimen from first series after drilling 132 holes; (c) specimen from second series after drilling 525 holes; and (d) specimen from third series after drilling 650 holes. Dry drilling. 
Table 4. Results of measuring wear of drills covered with TiAlCrYN coating

\begin{tabular}{l|c|l}
\hline \multicolumn{1}{c|}{ Coating } & Number of holes & \multicolumn{1}{c}{ Wear } \\
\hline Specimen 1 & 132 & Blade: $0.86-0.90 \mathrm{~mm}$; edge: $0.88-0.95 \mathrm{~mm}$; curvature radius: $0.90-0.99 \mathrm{~mm}$ \\
Specimen 2 & 525 & Blade: $0.45-0.52 \mathrm{~mm}$; edge: $0.42-0.47 \mathrm{~mm}$; curvature radius: $0.45-0.52 \mathrm{~mm}$ \\
Specimen 3 & 650 & Blade: $0.57-0.68 \mathrm{~mm}$; edge: $0.52-0.60 \mathrm{~mm}$; curvature radius: $0.57-0.65 \mathrm{~mm}$ \\
\hline
\end{tabular}

\section{CONCLUSIONS}

(1) A review of recent experimental results of studying nanocomposite multicomponent protective coatings with various chemical compositions (TiAlCrYN, TiAlSiBN, TiAlSiCuN, CrTiAlSiN, and $\mathrm{TiHfSiN} / \mathrm{NbN} / \mathrm{Al}_{2} \mathrm{O}_{3}$ ) has been carried out.

(2) The study results are indicate of the possibility of producing nanocomposite protective coatings with high mechanical and tribological characteristics by controlling the concentrations of the individual components and selecting the optimum parameters of deposition.

(3) The efficiency of using the processes of the duplex plasma nitriding of the specimens, which precedes the process of deposition, has been shown.

(4) The effect of the chemical bonds between the individual elements in the coating on the coefficient of friction is considered.

(5) The effect of the structural and phase composition of the nanocomposite coatings on their oxidation resistance at high temperatures has been found.

(6) The improvement of the performance characteristics of the drills made from the high-speed steel covered with the multicomponent nanostructured protective coating has been shown.

\section{NOTATION}

$R_{a}$ - parameter of roughness; SEM-EDX - scanning electron microscope equipped with attachment for energy dispersion analysis; $\mu-$ coefficient of friction; $k_{c}$-wear factor; $L_{C}$-adhesion strength; EELS - electron energy loss spectroscopy; TEMtransmission electron microscope; XRD-X-ray diffraction; XPS-X-ray photoelectron spectroscopy; $E$-modulus of elasticity.

\section{REFERENCES}

1. Azarenkov, N.A., Sobol', O.V., Pogrebnyak, A.D., Beresnev, V.M., Litovchenko, S.V., and Ivanov, O.N., Materialovedenie neravnovesnogo sostoyaniya modifitsirovannoi poverkhnosti: monografiya (Materials Science Aspects of Nonequilibrium State of Modified Surfaces: Monograph), Sumy: Sumskii Gos. Univ., 2012.

2. Bhushan, B., Nanotribology, nanomechanics and nanomaterials characterization, Phil. Trans. R. Soc., A., 2008, vol. 366, pp. 1351-1381.
3. Khomenko, A.V. and Lyashenko, Ya.A., Statistical theory of boundary friction of atomically smooth solid surfaces separated by lubricating film, Phys. Usp., 2012, vol. 55, pp. 1008-1034.

4. Khomenko, A.V. and Prodanov, N.V., Molecular dynamics of cleavage and flake formation during the interaction of a graphite surface with a rigid nanoasperity, Carbon, 2010, vol. 48, pp. 1234-1243.

5. Pogrebnyak, A.D., Ponomarev, A.G., Shpak, A.P., and Kunitskii, Yu.A., Use of micro- and nanoprobes for analysis small-sized 3D materials, nanosystems, and nanoobjects, Phys. Usp., 2012, vol. 55, pp. 270-300.

6. Koltunowicz, T.N., Zhukowski, P., Fedotova, V.V., Saad, A.M., and Fedotov, A.K., Hopping conductance in nanocomposites $\left(\mathrm{Fe}_{0.45} \mathrm{Co}_{0.45} \mathrm{Zr}_{0.10}\right)_{x}\left(\mathrm{Al}_{2} \mathrm{O}_{3}\right)_{1-x}$ manufactured by ion-beam sputtering of complex target in $\mathrm{Ar}+\mathrm{O}_{2}$ ambient, Acta Phys. Polonica, A, 2011, vol. 120, no. 1, pp. 39-42.

7. Hosson, J.T. and Cavaleiro, A., Nanostructured Coatings (Nanostructure Science and Technology), Springer Science + Business Media, LLC, 2006.

8. Veprek, S., The search for novel, superhard materials, J. Vac. Sci. Technol., A., 1999, vol. 17, no. 5, p. 2401.

9. Musil, J., Hard and superhard nanocomposite coatings, Surf. Coat. Technol., 2000, vol. 125, pp. 322-330.

10. Pogrebnyak, A.D., Shpak, A.P., Azarenkov, N.A., and Beresnev, V.M., Structure and properties of hard and superhard nanocomposite coatings, Phys. Usp., 2009, vol. 52, no. 1, pp. 29-54.

11. Pogrebnjak, A.D., Il'yashenko, M.V., Kaverin, M.V., et al., Physical and mechanical properties of the nanocomposite and combined $\mathrm{Ti}-\mathrm{N}-\mathrm{Si} / \mathrm{WC}-\mathrm{Co}-\mathrm{Cr} /$ and Ti-N-Si/ $\left(\mathrm{Cr}_{3} \mathrm{C}_{2}\right)_{75}-(\mathrm{NiCr})$ coatings, J. Nano- Electron. Phys., 2009, no. 4, pp. 101-110.

12. Larkin, A.V., Fedotov, A.K., Fedotova, J.A., Koltunowicz, T.N., and Zhukowski, P., Temperature and frequency dependences of impedance real part in the FeCoZr-doped PZT nanogranular composites, Mater. Sci.-Poland, 2012, vol. 30, no. 2, pp. 75-81.

13. Helmersson, U., Todorova, S., Barnett, S.A., Sundgren, J.E., Markert, L.C., et al., Growth of singlecrystal TiN/VN strained-layer superlattices with extremely high mechanical hardness, J. of Appl. Phys., 1987, vol. 62, p. 481.

14. Veprek, S. and Reiprich, S., A concept for the design of novel superhard coatings, Thin Solid Films, 1995, vol. 268, pp. 64-71.

15. PalDey, S. and Deevi, S.C., Single layer and multilayer wear resistant coatings of (Ti,Al)N: a Review, Mater. Sci. Eng., A., 2003, vol. 342, pp. 58-79.

16. Huq, M.Z. and Celis, L.B., Reproducibility of friction and wear results in ball-on-disc unidirectional sliding 
tests of TiN-alumina pairings, Wear, 1997, vol. 212, pp. 151-159.

17. Vmcoille, E., Celis, J.P., and Roos, J.R., Dry sliding wear of tin based ternary PVD coatings, Wear, 1993, vol. 165, pp. 41-49.

18. Mo, J.L., Zhu, M.H., Lei, B., et al., Comparison of tribological behaviours of $\mathrm{AlCrN}$ and TiAlN coatings deposited by physical vapor deposition, Wear, 2007, vol. 263, pp. 1423-1429.

19. Zhang, W. and Smith, J.R., Stoichiometry and adhesion of $\mathrm{Nb} / \mathrm{Al}_{2} \mathrm{O}_{3}$, Phys. Rev., B., 2000, vol. 61, pp. 16883-16889.

20. Liang, Sh.-Ch., Tsai, D.-Ch., Chang, Z.-Ch., et al., Thermally stable TiVCrZrHf nitride films as diffusion barriers in copper metallization, Electrochem. SolidState Lett., 2012, vol. 15, no. 1, pp. H5-H8.

21. Luo, Q., Zhou, Z., Rainforth, W.M., and Bolton, M., Effect of tribofilm formation on the dry sliding friction and wear properties of magnetron sputtered TiAlCrYN coatings, Tribol. Lett., 2009, vol. 34, no. 2, pp. 113124.

22. Shi, J., Muders, C.M., Kumar, A., Jiang, X., Pei, Z.L., Gong, J., and Sun, C., Study on nanocomposite Ti$\mathrm{Al}-\mathrm{Si}-\mathrm{Cu}-\mathrm{N}$ films with various $\mathrm{Si}$ contents deposited by cathodic vacuum arc ion plating, Appl. Surf. Sci., 2012, vol. 258, pp. 9642-9649.

23. Veprek, S., Männling, H.D., Jilek, M., and Holubar, P., Avoiding the high-temperature decomposition and softening of $\left(\mathrm{Al}_{1-x} \mathrm{Ti}_{x}\right) \mathrm{N}$ coatings by the formation of stable superhard nc- $\left(\mathrm{Al}_{1-x} \mathrm{Ti}_{x}\right) \mathrm{N} / \mathrm{a}-\mathrm{Si}_{3} \mathrm{~N}_{4}$ nanocomposite, Mater. Sci. Eng., A., 2004, vol. 366, pp. 202205.

24. Carvalho, S., Rebouta, L., Cavaleiro, A., Rocha, L.A., Gomes, J., and Alves, E., Microstructure and mechanical properties of nanocomposite $(\mathrm{Ti}, \mathrm{Si}, \mathrm{Al}) \mathrm{N}$ coatings, Thin Solid Films, 2001, vols. 398-399, pp. 391-396.

25. Chang, C.-L., Lee, J.-W., and Tseng, M.-D., Microstructure, corrosion and tribological behaviors of $\mathrm{Ti}-$ $\mathrm{Al}-\mathrm{Si}-\mathrm{N}$ coatings deposited by cathodic arc plasma deposition, Thin Solid Films, 2009, vol. 517, pp. 52315236.

26. Yu, D., Wang, C., Cheng, X., and Zhang, F., Microstructure and properties of $\mathrm{Ti}-\mathrm{Al}-\mathrm{Si}-\mathrm{N}$ coatings prepared by hybrid PVD technology, Thin Solid Films, 2009, vol. 517, pp. 4950-4955.

27. Barshilia, H.C., Acharya, S., and Ghosh, M., Performance evaluation of TiAlCrYN nanocomposite coatings deposited using four-cathode reactive unbalanced pulsed direct current magnetron sputtering system, Vacuum, 2010, vol. 85, pp. 411-420.

28. Musil, J., Vlcek, J., and Zeman, P., Hard amorphous nanocomposite coatings with oxidation resistance above $1000^{\circ} \mathrm{C}, A d v$. Appl. Ceram., 2008, vol. 107, no. 3, pp. $148-154$.

29. Fox-Rabinovich, G.S., Yamamoto, K., Beake, B.D., et al., Emergent behavior of nano-multilayered coatings during dry high-speed machining of hardened tool steels, Surf. Coat. Technol., 2010, vol. 204, pp. 34253435.

30. Lewis, D.B., Donohue, L.A., and Lembke, M., The influence of the yttrium content on the structure and properties of $\mathrm{Ti}_{1-x-y} z_{z} \mathrm{Al}_{x} \mathrm{Cr}_{y} \mathrm{Y}_{z} \mathrm{~N}$ PVD hard coatings, Surf. Coat. Technol., 1999, vol. 114, pp. 187-199.

31. Chang Y.-Y. and Hsiao C.-Y. High temperature oxidation resistance of multicomponent $\mathrm{Cr}-\mathrm{Ti}-\mathrm{Al}-\mathrm{Si}-\mathrm{N}$ coatings, Surf. Coat. Technol., 2009, vol. 204, 992-996.

32. Paternoster, C., Fabrizi, A., Cecchini, R., Kiryukhantsev-Korneev, Ph.V., Sheveyko, A., and Spigarelli, S., Thermal evolution and mechanical properties of hard $\mathrm{Ti}-\mathrm{Cr}-\mathrm{B}-\mathrm{N}$ and $\mathrm{Ti}-\mathrm{Al}-\mathrm{Si}-\mathrm{B}-\mathrm{N}$ coatings, Surf. Coat. Technol., 2008, vol. 203, pp. 736-740.

33. Komarov, F.F., Kamarou, A.A., Zukowski, P., Karwat, Cz., Sielanko, J., Kozak, Cz.M., and Kiszczak, K., Ion beam assisted deposition of metals layers using a novel one beam system, Vacuum, 2003, vol. 70, pp. 215-220.

34. Zukowski, P., Komarov, F.F., Karwat, Cz., Kistczak, K., Kozak, Cz., et al., Depth distribution of elements in monoatomic and compound coatings deposited onto copper and silicon by IBAD, Vacuum, 2009, vol. 83, pp. 204-207.

35. Bull, S.J., Rice-Evans, P.C., and Saleh, A., et al., Slow positron annihilation studies of defects in metal implanted tin coatings, Surf. Coat. Technol., 1997, vol. 91, pp. 7-12.

36. Bull, S.J., Failure mode maps in the thin film scratch adhesion test, Tribol. Int., 1997, vol. 30, no. 7, pp. 491498.

37. Pogrebnyak, A.D., Beresnev, V.M., Kaverina, A.Sh., Shypylenko, A.P., Kolisnichenko, O.V., Oyoshi, K., Takeda, Y., Murakami, H., Kolesnikov, D.A., and Prozorova, M.S., Formation of superhard $\mathrm{Ti}-\mathrm{Hf}-\mathrm{Si}-$ $\mathrm{N} / \mathrm{NbN} / \mathrm{Al}_{2} \mathrm{O}_{3}$ multilayer coatings for highly effective protection of steel, Tech. Phys. Lett., 2013, vol. 39, no. 2, pp. 189-192.

38. Chang Y.-Y. and Hsiao C.-Y., High temperature oxidation resistance of multicomponent $\mathrm{Cr}-\mathrm{Ti}-\mathrm{Al}-\mathrm{Si}-\mathrm{N}$ coatings, Surf. Coat. Technol., 2009, vol. 204, pp. 992996.

39. Veprek, S., Maritza Veprek-Heijman, J.G., Industrial applications of superhard nanocomposite coatings, Surf. Coat. Technol., 2008, vol. 202, pp. 5063-5073.

40. Kok, Y.N., Hovsepian, P.Eh., Luo, Q., Lewis, D.B., Wen, J.G., and Petrov, I., Influence of the bias voltage on the structure and the tribological performance of nanoscale multilayer C/Cr PVD coatings, Thin Solid Films, 2005, vol. 475, nos. 1-2, pp. 219-226.

41. Luo, Q., Robinson, G., Pittman, M., Howarth, M., Sim, W.M., Stalley, M.R., et al., Performance of nanostructured multilayer PVD coating TiAlN/VN in dry high speed milling of aerospace aluminium 7010T7651, Surf. Coat. Technol., 2005, vol. 200, pp. 123127.

Translated by D. Tkachuk 